\title{
EFFECT OF PARITY AND STAGE OF LACTATION ON MILK YIELD, COMPOSITION AND QUALITY OF ORGANIC SHEEP MILK
}

\author{
Š. Králíčková, M. Pokorná, J. Kuchtík, R. Filipčík
}

Received: November 8, 2011

\begin{abstract}
KRÁLÍČKOVÁ, Š., POKORNÁ, M., KUCHTÍK, J., FILIPČÍK, R.: Effect of parity and stage of lactation on milk yield, composition and quality of organic sheep milk. Acta univ. agric. et silvic. Mendel. Brun., 2012, LX, No. 1, pp. 71-78

Effect of parity (PA), stage of lactation (SL) and interaction of PA x SL on daily milk yield (DMY), composition (contents of total solids, fat, total protein and lactose) and quality (somatic cell and bacteria counts) of organic sheep milk were evaluated using 20 ewes of East Friesian which were reared on an organic farm in Habří. Ewes were on the $2^{\text {nd }}(n=10)$ and $3^{\text {rd }}(n=10)$ lactation. During the experiment ewes were reared on permanent pasture. The milk records and samplings were carried out on average $75^{\text {th }}, 132^{\text {th }}$ and $190^{\text {th }}$ day of lactation. All parameters were determined by standard methods. The PA had a significant effect only on somatic cell count (SCC). On the other hand, SL had a significant effect on daily milk yield (DMY), contents of total solids (TS), total protein (TP) and lactose (L). The SL also had a significant effect on total bacteria count (TBC), psychrotrophic bacteria count (PBC), total coliform count (TCC) and SCC. The interaction of the PA x SL had a significant effect on DMY, TS and TP contents and PBC. Positive and significant correlations were found among the SL and contents of TS and TP. Significant and positive correlation was observed between the PA and SCC, but on the other hand, significant and negative correlation was found between the SL and SCC.
\end{abstract}

organic milk, sheep, composition of milk, somatic cells, microorganisms

In the Czech Republic (CR) the sheep milk production is still a minor, however during last year was reported an increase in the numbers of dairy sheep whilst presently is reared more than 1500 milking ewes. Sheep milk has a high nutritional value, contains about 200 active substances (Horák et al., 2004) and is specific to markedly higher contents of total solids, fat, total protein, casein, whey protein and ash compared to cow's and goat's milk (Bencini and Pulina, 1997). Due to this, sheep milk is an excellent raw material especially for cheese production. In the CR, all milk is processed into above all cheese directly on the farms. Composition of sheep milk and its production are influenced by a number of factors while the parity and stage of lactation being among the most important (Oravcová et al., 2007). The effect of the parity and stage of lactation on milk composition in different sheep breeds were studied by Sevi et al. (2000), Aganga et al. (2002), Nuda et al. (2003), Oravcová et al. (2007), Kuchtík et al. (2008), Novotná et al. (2009) and Konečná et al. (2011).

The primary prerequisite for making high quality milk product is the production of high quality raw milk by dairy farms. Milk can be easily spoilt if the animals are given unsuitable feed or are handled in the wrong way before and during milking, or if the milk is handled incorrectly after milking, including the process of cooling (Jandal, 1996). The composition of microflora of milk can be very varied, because, as stated by Nester et al. (1998), milk is an excellent growth medium for many microorganisms. The milk in the mammary gland of healthy animals is almost sterile (Cempírková et al., 1997), but during and after milking the origin microflora is markedly changed due to secondary contamination. Sources of secondary contamination are most often the surface of the mammary gland, 
dust, water, feedstuff, litter and milking equipment (Smetana, 2009). Currently, closed milking system, better sanitary design of equipment, more efficient cleaning of udder and teats enable to produce raw milk with extremely low microbial contamination (Barbano et al., 2006).

Microbiological quality of raw milk is assessed in large extend by total bacteria count (TBC) and somatic cell count (SCC), and these parameters are routinely measured and compared. Microbial analysis and SCC have been used to diagnose mastitis in ewes. It was found that Staphylococcus aureus (together with Streptococcus agalactiae and Streptococcus uberis) persists as the main pathogen causing mastitis (Hariharan et al., 2004 and Vyletělová et al., 2010). According to Leitner et al. (2004), mastitis causes the changes in SCC and milk composition, while lactose content is lower, whey protein and albumin contents are significantly higher. As reported by Gonzalo et al. (2010), SCC and TBC are important to the farmers, cheese manufacturers, and consumers because they are the major factors in determining safety and hygienic quality of the final products. Thus, the European Union establishes the limits for TBC (Council Regulation EEC 853/2004) in ovine milk. According to above mentioned regulation, the maximal limit of TBC in raw milk is $1.5 .10^{6} \mathrm{CFU}$. $\mathrm{ml}^{-1}$. In the Czech Republic does not yet exist the standard for determining the limit of SCC in small ruminants, but e.g. Bianchi et al. (2004) reported the limit for subclinical mastitis at 500000 cells.ml $^{-1}$.

As mentioned by Hantsis-Zacharov and Halpern (2007) and Kumaresan et al. (2007), controlling the content of psychrotrophic bacteria is also very important, because these Gram-negative bacteria are able to produce heat-stable extracellular proteases, as well as lipases, that are potentially harmful for technological quality of milk and milk products. Proteases are associated with bitterness in milk and reduces yield of soft cheeses and lipases cause flavour defects in cheeses and other milk products. In Europe, psychrotrophic bacteria count (PBC) of raw milk should not exceed $50.10^{3} \mathrm{CFU}_{\mathrm{ml}}{ }^{-1}$ (Cempírková and Mikulová, 2009). Furthermore, according to Vyletělová and Hanuš (2000) and Cempírková and Mikulová (2009), lipolytic and proteolytic activities, supported by psychrotrophic bacteria, are considered insignificant at PBC lower than $10^{6}$ CFU.ml-1.

The sheep milk quality is determined not only by its nutrient content but also by its hygienic aspects. Therefore, the objective of this study was to evaluate the effect of the parity and stage of lactation on milk yield, composition (TS, F, TP and L) and quality (SCC, TBC, PBC and TCC) of organic sheep milk.

\section{MATERIALS AND METHODS}

Evaluation of effect of parity (PA), stage of lactation (SL) and interaction of PA x SL on daily milk yield, composition and quality (somatic cell and bacteria counts) of organic sheep milk were evaluated using
20 ewes of East Friesian breed which were reared on an organic farm in Habrí. The farm is situated at an altitude of $430 \mathrm{~m}$ above sea level with an average annual temperature of $6.9^{\circ} \mathrm{C}$ and annual precipitation of $865 \mathrm{~mm}$. Samples were obtained from 10 ewes on the second lactation (PA2) and from 10 ewes on the third lactation (PA3). Individual milk records and samplings were carried out three times in the period from May to September 2009 (on the average $75^{\text {th }}, 132^{\text {th }}$ and $190^{\text {th }}$ day of lactation). During the experiment, the daily feed ration of ewes consisted of permanent pasture (ad libitum), organic mineral lick (ad libitum) and organic oat $(0.5 \mathrm{~kg} / \mathrm{ewe} /$ day). The milking of ewes was carried out, during the experiment, once a day (8 am). During the experiment, all of the ewes were reared in one flock under identical conditions without any discernible differences in nutrition or management.

Individual milk samples were cooled to $5-8{ }^{\circ} \mathrm{C}$ and transported in a thermo-box to a specialized milk laboratory at Mendel University in Brno and to the private Laboratory for Milk Analysis in Brno-Tuřany (Bohemian-Moravian Association of Breeders, a. s.). As part of the laboratory analysis, the following determinations of milk composition and quality were carried out: total solids (TS), fat (F), total protein (TP) and lactose (L) contents, numbers of total bacteria, psychrotrophs and total coliforms. The evaluation of somatic cell count (SCC) and daily milk yield (DMY) was also an integral part of this study.

TS content (\%) was determined gravimetrically; by over drying at $102{ }^{\circ} \mathrm{C}$ to constant weight (Czech technical Standard ISO No. 6731, 1998). Fat content (\%) was determined by Gerber's acidobutyrometric method (Czech Technical Standard ISO No. 2446, 2010). TP content (\%) was determined using a PROMILK apparatus (manufactured by the Danish Co. Foss Electric; Czech Technical Standard No. 570530, 1974). L content (\%) was determined polarimetrically (Czech Technical Standard No. 570530, 1974). SCC was determined using fluoro-opto-electronic apparatus BENTLEY 2500 (Czech Technical Standard EN ISO No. 13366-2, 2007). Samples for microbiological determination were milked by hand and were collected in sterile plastic containers. Before sampling the milker washed his hands carefully. Numbers of total bacteria, psychrotrophs and total coliforms were determined by standard plate count method. Milk samples were diluted by the decimal dilution $(9 \mathrm{ml}$ of distilled water and $1 \mathrm{ml}$ of milk sample). Total bacteria count (TBC) was determined on plate count agar with skimmed milk (PCA, Biokar Diagnostic, France); inoculated plates were incubated at $30{ }^{\circ} \mathrm{C}$ for 72 hours (Czech Technical Standard EN ISO No. 4833, 2003). Samples for the determination of psychrotrophic bacteria count (PBC) were spread also on PCA with skimmed milk (Biokar Diagnostic; France); plates were incubated at $6.5^{\circ} \mathrm{C}$ for 10 days according to the Czech Technical Standard ISO No. 6730, 2007. Total coliform count (TCC) was monitored in process of 
cultivation on VRBL agar (Biokar Diagnostic; France) at $37^{\circ} \mathrm{C}$ for 24 hours (Czech Technical Standard ISO No. 5541-1, 1996). The colonies of microorganisms which grew out in Petri dishes were counted after termination of cultivation, while the number of these colonies were recalculated using the following mathematical formula. The final bacterial counts are expressed in specific units CFU (Colony Forming Units) per $1 \mathrm{ml}$ of milk sample.

$$
N=\frac{\Sigma C}{V \times d \times\left(n_{1}+0,1 \times n_{2}\right)},
$$

where:

$\mathrm{N}$......number of CFU in $1 \mathrm{ml}$ of milk sample

$\Sigma C$....the sum of colonies grown in Petri dishes at two consecutive dilutions

V.......volume of inoculum

d........first dilution factor used to calculate the dilution $n_{1}$......number of Petri dishes used for the calculation of the first dilution

$\mathrm{n}_{2} \ldots . .$. number of Petri dishes used for the calculation of the second dilution.

Recorded data were statistically analyzed using the least-squares method. The systematic effects were PA (two classes), the SL (three classes) and the interaction of PA x SL. Statistical analysis was carried out using the mathematical-statistical package STATISTICA version 9.0.

\section{RESULTS AND DISCUSSION}

Effect of parity (PA), stage of lactation (SL) and the interaction of PA x SL on daily milk yield and basic milk composition (contents of total solids, fat, total protein and lactose) is presented in Table I.

The PA had no significant effect on daily milk yield (DMY), which is in line with the results published by Pokorná et al. (2010), but on the other hand, Oravcová et al. (2006) found a significant

I: L.S.M. and S.E.Mvalues of daily milk yield and particular components of organic sheep milk in parities $2^{\text {nd }}$ and $3^{\text {rd }}$

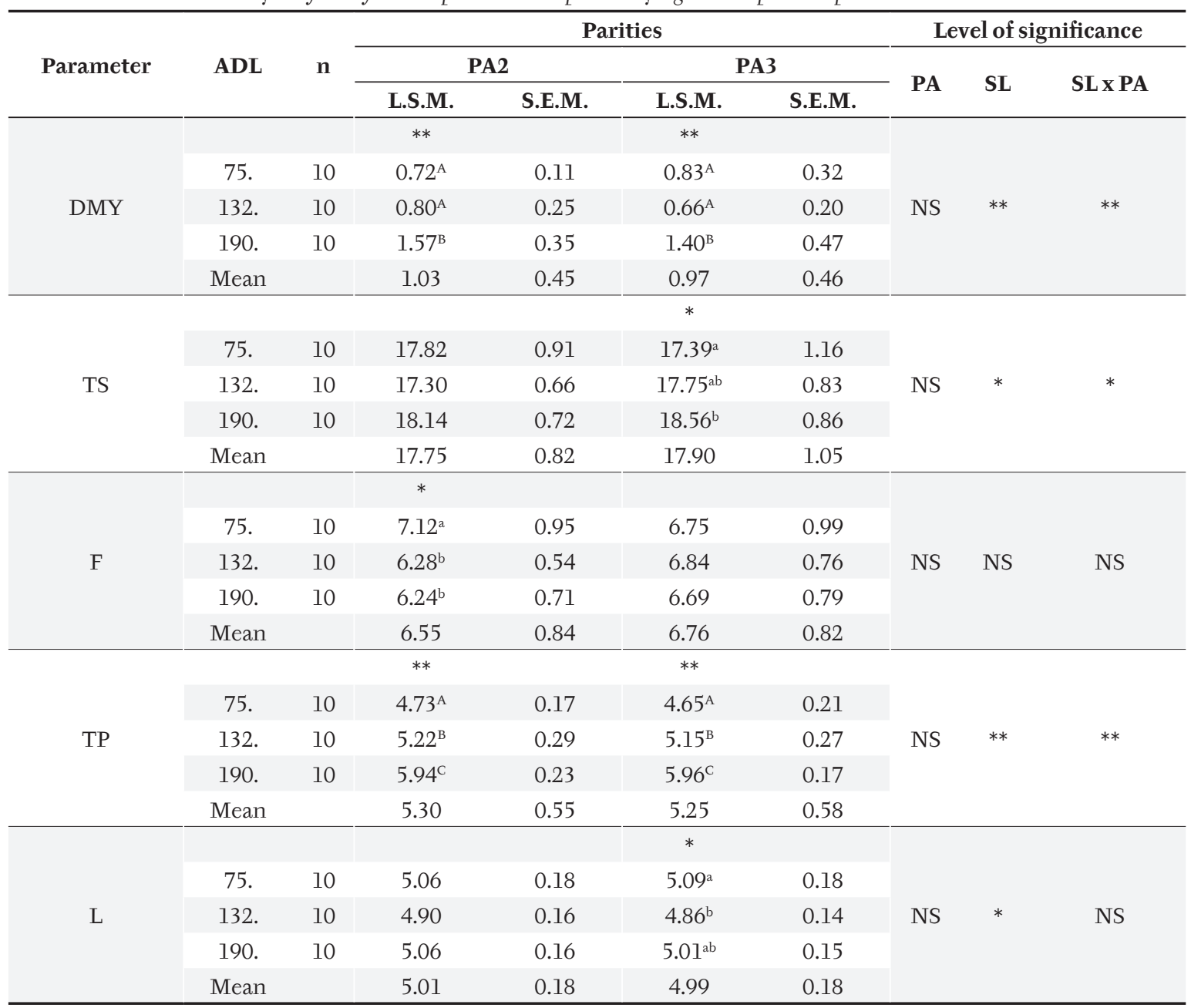

$\mathrm{ADL}=$ average day of lactation; $\mathrm{SL}=$ stage of lactation; $\mathrm{n}=$ number of cases; $\mathrm{PA}=$ parity; Mean = average value of lactation; DMY = daily milk yield $(\mathrm{kg}) ; \mathrm{TS}=$ total solids content $(\%) ; \mathrm{F}=$ fat content $(\%) ; \mathrm{TP}=$ total protein content $(\%) ; \mathrm{L}=\mathrm{lactose}$ content (\%); ABC values in the same columns were significantly different $(\mathrm{P} \leq 0.01)$; abc values in the same columns were significantly different $(\mathrm{P} \leq 0.05) ; * *=$ statistically highly significant $(\mathrm{P} \leq 0.01) ; *=$ statistically significant $(\mathrm{P} \leq 0.05)$; $\mathrm{NS}=$ statistically non-significant $(\mathrm{P}>0.05)$ 
effect of this factor on DMY. Furthermore, the PA had no significant effect on contents of total solids (TS), fat (F), total protein (TP) and lactose (L), which correspond to the results published by Pokorná et al. (2010). On the contrary, Sevi et al. (2000) found a significant effect of this factor on contents of all milk components under their study; also Konečná et al. (2011) reported a significant effect of the PA on contents of total solids (TS), fat (F) and total protein (TP). However, Marìa and Gabiña (1993) stated that the PA affects only contents of TS not F. The average DMY and lactose (L) content were during the whole lactation period slightly lower for the third lactation (PA3) compared with the second (PA2) lactation, which is consistent with the results published by Ploumi et al. (1998), Novotná et al. (2009) and Pokorná et al. (2010). The average value of content of TP was slightly higher on the PA2 in our experiment, however on the other hand, Sevi et al. (2000) and Oravcová et al. (2007) reported higher average TP content on the PA3. With regard to the average contents of TS and F, these were higher on the PA3, which is in agreement with the results of study carried out by Sevi et al. (2000). On the other hand Konečná et al. (2011) reported the opposite trend.

The SL had a significant effect on DMY, which is consistent with the results published by OchoaCordero et al. (2002). Also, the contents of TS, TP and L were affected by the SL. The same conclusions also report Bencini and Pulina (1997), Sevi et al. (2000; 2004) and Pokorná et al. (2010). On the other hand, F content was not affected by this factor. DMY of ewes was relatively stable between the $75^{\text {th }}$ and $132^{\text {nd }}$ day of lactation (from 0.66 to $0.83 \mathrm{~kg}$ ), but on the $190^{\text {th }}$ day of lactation the DMY greatly increased in both lactations (1.57 and $1.40 \mathrm{~kg}$ ). In contrast, Nuda et al. (2003) and Kuchtík et al. (2008) reported the opposite trend. In our opinion, the low DMY till the $132^{\text {nd }}$ day of lactation was probably caused by the inadequate production of green mass on pasture as a result of low rainfall from May to July. Ploumi et al. (1998) also point to the fact that longterm droughts and high temperatures lead to a drop in milk yield. Contents of TS and TP increased with advancing lactation, the same trend of L.S.M. values of TS and TP published Sevi et al. $(2000 ; 2004)$ and Jaramillo et al. (2008) in their experiments. On the contrary, F content in our study gradually decreased during the lactation period, which is not in line with the results published by Aganga et al. (2002), Sevi et al. (2004), Sahan et al. (2005) and Novotná et al. (2009). The content of $L$ was relatively well balanced during the whole observation; this conclusion corresponds with results published by Pugliese et al. (2000), Kuchtík et al. (2008) and Novotná et al. (2009). According to the Table I, we can see that the milk protein was the most variable component in comparison with the other components of the milk. Finally, it is necessary to complete that the interaction of PA x SL had a significant effect on DMY, TS and TP contents; on the other hand this factor had no effect on $\mathrm{F}$ and $\mathrm{L}$ contents. By contrast,
Sevi et al. (2000) did not find a significant effect of the interaction of PA x SL on any of the above mentioned parameters of sheep's milk.

The effect of the PA, SL and its interaction on somatic cell and bacteria counts is summarized in Table II.

The PA had a significant effect on somatic cell count (SCC), which is not consistent with findings of Sevi et al. (2000). On the other hand, as mentioned by Pugliese et al. (2000), SCC significantly increased from PA2 to the fourth lactation, which is in line with results of our experiment, while L.S.M values of SCC were significantly higher in ewes on the PA3 as compared to ewes on the PA2. SCC was significantly effected also by the SL, which corresponds to conclusions published by Sevi et al. (2004). However, Pugliese et al. (2000), Sevi et al. (2000) and Pokorná et al. (2009) did not find a significant effect of this factor on SCC during their study. As regards SCC in ewes on the PA3, L.S.M. values were between the $75^{\text {th }}$ and $132^{\text {nd }}$ day of lactation almost identical, however, the $190^{\text {th }}$ day of lactation SCC markedly decreased. A similar trend between the $75^{\text {th }}$ and $132^{\text {nd }}$ day of lactation was reported by Paape et al. (2006). The interaction of PA x SL had no significant effect on SCC, which is in line with results mentioned by Sevi et al. (2000). The L.S.M. values of SCC ranged from 28.00 to 117.40 thousands. $\mathrm{ml}^{-1}$ during the whole lactation. As regards SCC, it is necessary to add that none of the ewes did not suffer from subclinical mastitis during the observation. By the way, Bianchi et al. (2004) reported limit for subclinical mastitis at 500000 of somatic cell per Iml of milk sample.

The PA had no significant effect on total bacteria count (TBC) and psychrotrophic bacteria count (PBC). On the contrary, the SL had a significant effect on TBC, which is consistent with results published by Micari et al. (2002). It should be pointed out that values of TBC founded by these authors are markedly higher than our data. Talevski et al. (2009) and Malá et al. (2010) also reported in their studies higher values of TBC using the same system of milking. Furthermore, the SL also significantly effected PBC which is in agreement with Sevi et al. (2000). In the Table II we can see the similar dynamics of TBC and PBC values during the lactation period, while between the $75^{\text {th }}$ and $132^{\text {nd }}$ day of lactation was found in both lactations a significant increase their numbers, however after that, on the $190^{\text {th }}$ day of lactation TBC and PBC decreased. As regards evaluating of the interaction of PA x SL, this factor influenced only PBC. In relation to above mentioned should be added that L.S.M. values of TBC did not exceed 1.5.106 CFU. $\mathrm{ml}^{-1}$, which is maximal limit of TBC for raw sheep milk (Regulation of the European Parliament and Council No. 853/2004).

The PA had no significant effect on total coliform count (TCC). On the other hand, the SL had a significant effect on TCC, which corresponds with results published by Sevi et al. (2000; and 2004). Coliforms as important indicators of primary and 
II: L.S.M. and S.E.Mvalues of somatic cell and bacteria counts of organic sheep milk in parities $2^{\text {nd }}$ and $3^{\text {rd }}$

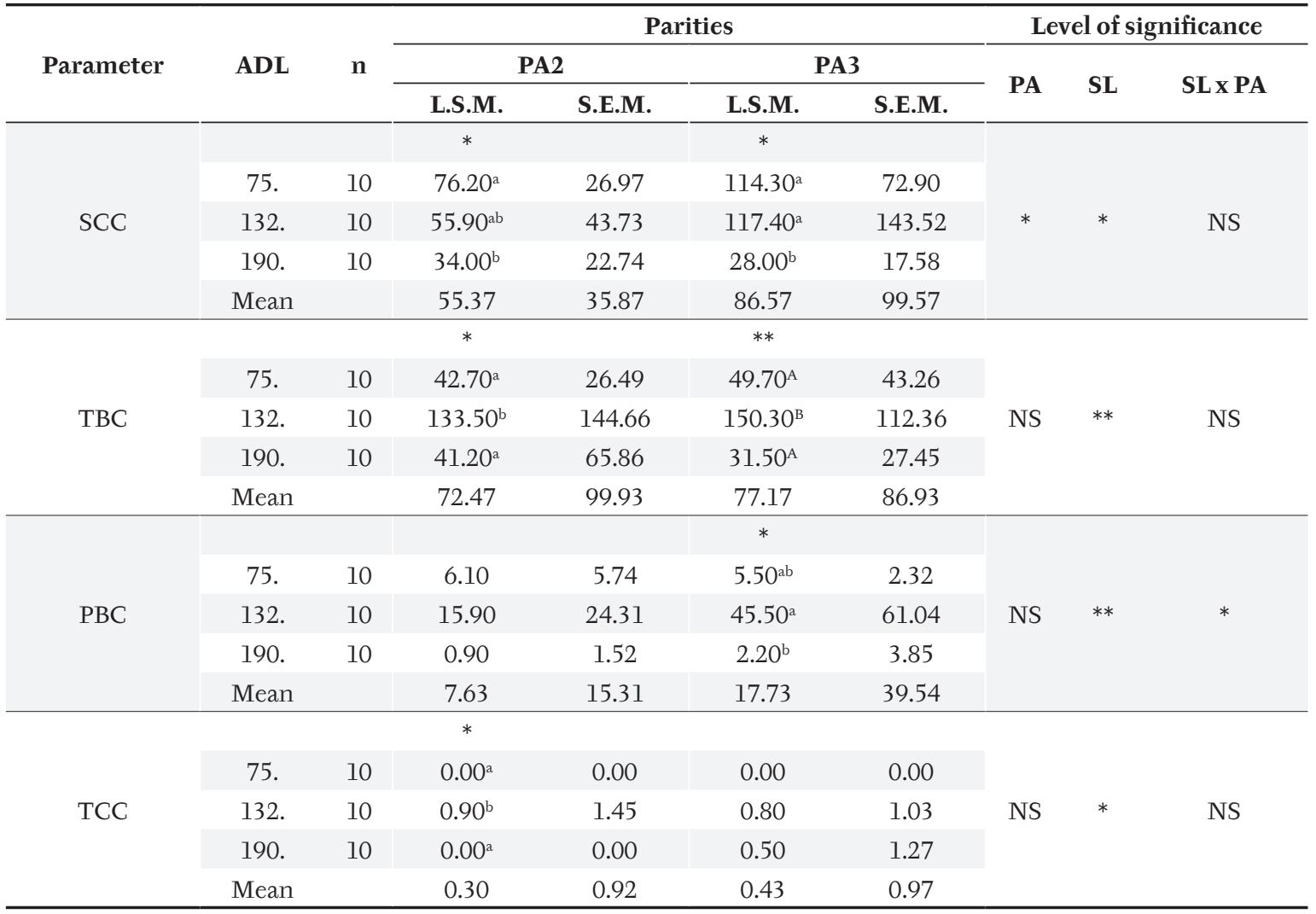

$\mathrm{ADL}=$ average day of lactation; $\mathrm{SL}=$ stage of lactation; $\mathrm{n}=$ number of cases; $\mathrm{PA}=$ parity; Mean = average value of lactation; SCC = somatic cell count (thousands.ml-1); TBC = total bacteria count (CFU.ml-1 $)$ PBC = psychrotrophic bacteria count (CFU.ml-1); TCC = total coliform count $\left(\mathrm{CFU} \cdot \mathrm{ml}^{-1}\right)$; ABC values in the same columns were significantly different (P $\left.\leq 0.01\right)$; abc values in the same columns were significantly different $(\mathrm{P} \leq 0.05) ; * *=$ statistically highly significant $(\mathrm{P} \leq 0.01)$; $*$ = statistically significant $(\mathrm{P} \leq 0.05) ; \mathrm{NS}=$ statistically non-significant $(\mathrm{P}>0.05)$

III: Pearson correlations among parity, stage of lactation and all researched parametrs of milk

\begin{tabular}{cccccccccc}
\hline & DMY & TS & F & TP & L & SCC & TBC & PBC & TCC \\
\hline PA & -0.07 & 0.08 & 0.13 & -0.04 & -0.05 & $0.21^{*}$ & 0.03 & 0.17 & 0.07 \\
SL & $0.63^{* *}$ & $0.33^{* *}$ & $-0,23$ & $0.92^{* *}$ & -0.09 & $-0.35^{* *}$ & -0.04 & -0.06 & 0.11 \\
\hline
\end{tabular}

$\mathrm{PA}=$ parity; $\mathrm{SL}=$ stage of lactation; $\mathrm{DMY}=$ daily milk yield; $\mathrm{TS}=$ total solids content; $\mathrm{F}=$ fat content; $\mathrm{TP}=$ total protein content; $\mathrm{L}=$ lactose content; $\mathrm{SCC}=$ somatic cell count; $\mathrm{TBC}=$ total bacteria count; $\mathrm{PBC}=$ psychrotrophic bacteria count; TCC $=$ total coliform count; $* *=$ statistically highly significant $(\mathrm{P} \leq 0.01){ }^{*}=$ statistically significant $(\mathrm{P} \leq 0.05)$

secondary contamination of raw milk (Görner and Valík, 2004) occurred in milk samples only sporadically, while $77 \%$ of all milk samples were negative for these bacteria. Under study, TCC was very-well balanced on both lactations. A similar trend was reported by Sevi et al. (2000). Our observed values of TCC were markedly lower as compared to those of Sevi et al. (2000) and Malá et al. (2010). This fact points to the observing good hygienic principles during milking. Finally, it is necessary to complete that the effect of the interaction of PA x SL was not reported, which is in line with the conclusion published by Sevi et al. (2000).

Table III shows correlations among PA, SL and DMY, basic milk components and quality parameters of sheep milk. As we can see, significant and positive correlation was found between the PA and SCC. This means that with increasing order of lactation also increased the number of somatic cells, which is consistent with results published by Pugliese et al. (2000). On the other hand, as regards correlation SL vs. SCC this was significant, but negative. On the contrary, Luengo et al. (2004) and Raynal-Ljutovac et al. (2006) published the opposite trends; however, Paape et al. (2006) consistently with our results reported a decrease of SCC with advanced stage of lactation. Furthermore, significant and positive correlations were found among the SL and DMY, contents of TS and TP. This means that contents of TS and TP, as well as DMY, increased with advancing lactation, which is in line with results reported by Sevi et al. (2000). 


\section{SUMMARY}

Evaluation of the effect of parity, stage of lactation and interaction of PA x SL on daily milk yield, composition (contents of total solids, fat, total protein and lactose) and quality (somatic cell and bacteria counts) of organic milk of East Friesian sheep was carried out on organic farm in Habří in 2009. Ten ewes were on the second lactation and other ten ewes were on the third parity. All ewes were reared, till the end of our study, on permanent pasture and after weaning all ewes began to be machine-milked once a day. Samples for microbiological determination were milked by hand and were collected in sterile plastic containers. During the experiment, the daily feed ration of ewes consisted of permanent pasture (ad libitum), organic mineral lick (ad libitum) and organic oat (0.5kg/ewe/day). The milk records and samplings were carried out three times in the period from May to September, specifically on the average $75^{\text {th }}, 132^{\text {th }}$ and $190^{\text {th }}$ day of lactation. The milk analysis were carried out using standard methods. The parity (PA) had no significant effect on all monitored indicators of milk, with the exception of somatic cell count (SCC). On the other hand, the stage of lactation (SL) had a significant effect on daily milk yield (DMY), contents of total solids (TS), total protein (TP) and lactose (L). Furthermore, the SL had a significant effect on total bacteria count (TBC), psychrotrophic bacteria count (PBC), total coliform count (TCC) and SCC. The evaluation of the interaction of the PA x SL was also an integral part of this study. The above mentioned factor had a significant effect on DMY, TS and TP contents and PBC. Under study, the milk protein was the most variable component of the milk. SCC as well as bacteria counts were very-well balanced on both lactations and relatively very low during the lactation period. Significant and positive correlations were found among the SL and contents of TS and TP. Furthermore, significant and positive correlation was observed between the PA and SCC, but on the other hand, significant however negative correlation was found between the SL and SCC.

\section{Acknowledgements}

This study was supported by internal grant project of Mendel University IGA TP 08/2011 and by project No. QH91271, which is financed by the Ministry of Agriculture of the Czech Republic.

\section{REFERENCES}

AGANGA, A. A., AMARTEIFIO, J. O., NKILE, N., 2002: Effect of stage of lactation on nutrient composition of Tswana sheep and goat's milk. Journal of Food Composition and Analysis, 15, 533-543.

BARBANO, D. M., MA, Y., SANTOS, M. V., 2006: Influence of raw milk quality on fluid milk shelf life. Journal of Dairy Science, 89, 15-19.

BENCINI, R., PULINA, G., 1997: The quality of sheep milk: A rewiew. Wool Technology and Sheep Breeding, 45, 3: 182-220.

BIANCHI, L., BOLLA, A., BUDELLI, E., CAROVI, A., FAZOLI, C., PAUSELLI, M., DURANTI, E., 2004: Effect of udder health status and lactation phase on the characteristics of Sardinian ewe milk. Journal of Dairy Science, 87, 2401-2408.

CEMPÍRKOVÁ, R., LUKÁŠOVÁ, J., HEJLOVÁ, Š., 1997: Mikrobiologie potravin. 1. vyd. Jihočeská univerzita v Českých Budějovicích, 165 s.

CEMPÍRKOVÁ, R., MIKULOVÁ, M., 2009:Incidence of psychrotrophic lipolytic bacteri in cow's raw milk. Czech Journal of Animal Science, 54, 65-73.

Czech Technical Standard EN ISO No. 133662, 2007: Milk - Enumeration of somatic cells Part 2: Guidance on the operation of fluoro-optoelectronic counters. $16 \mathrm{pp}$.

Czech Technical Standard ISO No. 2446, 2010: Milk - Determination of fat content (Routine method). Czech Standards Institute, Prague, 16 pp.
Czech Technical Standard ISO No. 4833, 2003: Microbiology of food and animal feeding stuffs Horizontal method for the enumeration of microorganisms - Colony count technique at $30^{\circ} \mathrm{C} .8 \mathrm{pp}$.

Czech Technical Standard ISO No. 5541-1, 1996: Milk and milk products - Enumeration of coliforms Part 1: Colony count technique at $30^{\circ} \mathrm{C} .16 \mathrm{pp}$.

Czech Technical Standard No. 570530, 1974: Methods for testing of milk and milk products. Czech Standards Institute, Prague, 108 pp.

Czech Technical Standard No. 6730, 2007: Milk - Enumeration of colony-forming units of psychrotrophic microorganisms - Colony-count technique at $6.5^{\circ} \mathrm{C} .12 \mathrm{pp}$.

Czech Technical Standard ISO No. 6731, 1998: Milk, cream and evaporated milk - Determination of total solids content (Reference method). Czech Standards Institute, Prague, 8 pp.

GONZALO, C., CARRIEDO, J. A., GARCÍAJIMENO, M. C., PÉREZ-BILBAO, M., DE LA FUENTE, L. F., 2010: Factors influencing variation of bulk milk antibiotic residue occurrence, somatic cell count, and total bacteria count in dairy sheep flocks. Journal of Dairy Science, 93, 1587-1595.

GÖRNER, F., VALÍK, L., 2004: Aplikovanámikrobiológia poživatín. 1. vyd. Bratislava: Malé centrum, $528 \mathrm{~s}$.

HANTSIS-ZACHAROV, E., HALPERN, M., 2007: Culturable psychrotrophic bacterial communities in raw milk and their proteolytic and lipolytic traits. Applied Environmental Microbiology, 73, 7162-7168. 
HARIHARAN,H.,DONACHIE,W.,MACALDOWIE, C., KEEFE, G., 2004: Bacteriology and somatic cell counts in milk samples from ewes on a Scottish farm. The Canadian Journal of Veterinary Research, 68, 188-192.

HORÁK, F. et al., 2004: Ovce a jejich chov. 1. vyd. Praha: Brázda, 66 s.

JANDAL, J. M., 1996: Comparative aspects of goat and sheep milk. Small Ruminant Research, 22, 177-185.

JARAMILLO, D. P., ZAMORA, A., GUAMIS, B., RODRIGUES, M., TRUJILLO, A. J., 2008: Cheesemaking aptitude of two Spain dairy ewe breeds: Changes during lactation and relationships between physico-chemical and technological properties. Small Ruminant Research, 78, 48-55.

KONEČNÁ, L., KUCHTÍK, J., KRÁLÍČKOVÁ, Š., POKORNÁ, M., 201l: Vliv pořadí laktace na dojivost a základní složení organického ovčího mléka u bahnic, kříženců plemene Lacaune a Východofríská ovce. Farmářská výroba sýrů a kysaných mléčných výrobků VIII, 40-41.

KUCHTÍK,J., ŠUSTOVÁ,K.,URBAN, T.,ZAPLETAL, D., 2008: Effect of the stage of lactation on milk composition, its properties and the quality of rennet curdling in East Friesian ewes. Czech Journal of Animal Science, 53, 55-63.

KUMARESAN, G., ANNALVILLI, R., SIVAKUMAR, K., 2007: Psychrotrophic spoilage of raw milk at different temperatures of storage. Journal of Applied Science Research, 3, 1383-1387.

LEITNER, G., CHAFFER, M., SHAMAY, A., SHAPIRO, F., MERIN, U., EZRA, E., SARAN, A., SILANIKOVA, N., 2004: Changes in milk composition as affected by subclinical mastitis in sheep. Journal of Dairy Science, 87, 46-52.

LUENGO, C., SANCHEZ, A., CORRALES, J. C., FERNANDES, C., CONTRERAS, A., 2004: Influence od intramammary infection and noninfection factors on somatic cell counts in dairy goats. Journal Dairy Research, 71, 169-174.

MALÁ, G., ŠVEJCAROVÁ, M., KNÍŽEK, J., PEROUTKOVÁ, J., 2010: Je mikrobiologická kvalita ovčího mléka ovlivněna způsobem dojení? Sborník referátů ze semináře farmářská výroba sýrů a kysaných mléčných výrobků VII, MENDELU v Brně: 37-38.

MARİA, G., GABIÑA, D., 1993: Non-genetic effects on milk production of Latxa ewes. Small Ruminant Research, 12, 61-67.

MICARI, P., CARIDI, A., COLACINO, T., CAPARRA, P., CUFARO, A., 2002: Physicochemical, microbiological and coagulating properties of ewe's milk produces on the Calabrian Mount Poro Plateau. International Journal of Dairy Technology, 55, 204-210.

NESTER, E. W., ROBERTS, C. E., PEARSALL, N. N., ANDERSON, D. G., NESTER, M. T., 1998: Microbiology of food and baverages in Microbiology: A human perspective. 2. vyd. WCB/McGRAW-Hill, $764 \mathrm{~s}$.
NOVOTNÁ, L., KUCHTÍK, J., ŠUSTOVÁ, K., ZAPLETAL, D., FILIPČÍK, R., 2009: Effects of lactation stage and parity on milk yield, composition and properties of organic sheep milk. Journal of Applied Animal Research, 36, 71-76.

NUDA, A., FELIGINI, M., BATTACONE, G., MACCIOTTA, N. P. P., PULINA, G., 2003: Effect of lactation stage, parity, $\beta$-lactoglobulin genotype and milk SCC on whey protein composition on Sarda dairy ewes. Italian Journal of Animal Science, 2, 29-39.

OCHOA-CORDERO, M. A., TORRES-HERNÁNDEZ, G., OCHOA-ALFARO, A. E., VEGA-ROQUE, L., MANDEVILLE, P. B., 2002: Milk yield and composition of Rambouillet ewes under intensive management. Small Ruminant Research, 43, 269-274.

ORAVCOVÁ, M., MARGETÍN, M., PEŠKOVIČOVÁ, D., DAŇO, J., MILERSKI, M., HETÉNYI, L., POLÁK, P., 2007: Factors affecting ewe's milk fat and protein content and relationships between milk yield and milk components. Czech Journal of Animal Science, 52, 189-198.

ORAVCOVÁ, M., MARGETÍN, M., PEŠKOVIČOVÁ, D., DAŇO, J., MILERSKI, M., HETÉNYI, L., POLÁK, P., 2006: Factors effecting milk yield and ewe's lactation curves estimated with Testday model. Czech Journal of Animal Science, 51, 483-490.

PAAPE, M. J., WIGGANS, G. R., BANNERMAN, D. D., THOMAS, D. L., SANDERS, A. H., CONTRERAS, A., MORONI, P., MILLER, R. H., 2006: Monitoring goat and sheep milk somatic cell counts. Small Ruminant Research, 68, 124-125.

PLOUMI, K., BELIBASAKI, S., TRIANTAPHYLLIDIS, G., 1998: Some factors affecting daily milk yield and composition in a flock of Chios ewes. Small Ruminant Research, 28, 89-92.

POKORNÁ, M., KUCHTÍK, J., FILIPČÍK, R., 2010: Effect of chosen factors on milk yield, basic composition and properties of milk of East Friesian sheep. Výzkum v chovu skotu / Cattle Research 4, 59-67.

PUGLIESE, C., ACCIAIOLI, A., RAPACCINI, S., PARISI, G., FRANCI, O., 2000: Evolution of chemical composition, somatic cell count and renneting properties of the milk of Massese Ewes. Small Ruminant Reseach, 35, 71-80.

RAYNAL-LJUTOVAC, K., PIRISI, A., DE CRÉMOUX, R., GONZALO, C., 2006: Somatic cell of goat and sheep milk: Analytical, sanitary, productive and technological aspects. Small Ruminant Research, 68, 126-144.

Regulation (EC) No. 853/2004 of the European Parliament and of the Council of 29 April 2004, laying down specific hygiene rules for food of animal origin.

ŞAHAN, N., SAY, D., KAÇAR, A., 2005: Changes in chemical and mineral contents of Awassi ewe's milk during lactation. Turkish journal of Veterinary Animal Research, 29, 589-593. 
SEVI, A., TAIBI, L., ALBENZIO, M., MUSCIO, A., ANNICCHIARICO, G., 2000: Efefct of parity on milk yield, composition, somatic cell count, renneting parameters and bacteria counts of Comisana ewes. Small Ruminant Research, 37, 99-107.

SEVI, A., ALBENZIO, M., MARINO, R., SANTILLO, A., MUSCIO, A., 2004: Effect of lambing season and stage of lactation on ewe milk quality. Small Ruminant Research, 51, 251-259.

SMETANA, P., HLAVÁČEK, J., SAMKOVÁ, E., ROZSYPAL, R., 2009: Metodika pro praxi: Faremní zpracování mléka $\mathrm{v}$ ekologickém zemědělství. Bioinstitut, Olomouc. 21-24 s.
TALEVSKI， G., ČOBANOVA-VASILEVSKA， R., SRBINOVSKA, S., SIRETA, Z., 2009: Quality of the sheep milk as a raw material in dairy industry of Macedonia. Biotechnology in Animal Husbandry, 25 (5-6), 971-977.

VYLETĚLOVÁ, M., HANUŠ, O., 2000: Effect of contamination by Pseudomonas fluorescens on principal components and technological parameters of pasteurized milk during storage. Czech Journal of Food Science, 18 (6), 224-234.

VYLETĚLOVÁ, M., NEJESCHLEBOVÁ, L., HANUŠ, O., 2010: Sledování hlavních mastitidních patogenů. Náš chov, 2, 68-71.

Address

Ing. Šárka Králíčková, prof. Dr. Ing. Jan Kuchtík, Ing. Michaela Pokorná, Ing. Radek Filipčík, Ph.D., Ústav chovu a šlechtění zvířat, Mendelova univerzita v Brně, Zemědělská 1, 61300 Brno, Česká republika, e-mail: xkralic0@node.mendelu.cz 